\title{
Effects of water and soil conservation works on runoff and sediment variation in the areas with high and coarse sediment yield of the middle Yellow River
}

\author{
Wei Ying SUN, Pan ZHANG, Li LI, and Jiang Nan CHEN
}

Key Laboratory of Soil and Water Loss Process and Control on the Loess Plateau of Ministry of Water Resources, Yellow River Institute of Hydraulic Research, Zhengzhou 450003, China

\begin{abstract}
The areas with high and coarse sediment yield of the middle Yellow River is well known for its severe erosion, high sediment yields. Since 1982 when the 8 key soil and water conservation harnessing regions has been built, the ecological environment has been gradually improved and the amount of sediment and runoff entering the Yellow River has been reduced continuously. Some researchers considered that it was owing to the water and soil conservation works (WSCW), while others believed that it was caused by the rainfall variation, but this has not been quantified for the effect respectively. This paper deals with the effects of WSCW on runoff and sediment variation. The study has been carried out in the Sanchuanhe River watershed, where was listed as one of the $8 \mathrm{key}$ soil and water conservation harnessing regions. The results show that the contribution rate of human activities was $80.2 \%$ after 1 st harnessing stage (1970-1979), 43.0\% after 2nd harnessing stage (1980-1989), in 3rd harnessing stage (1990-1996) it reached $98.4 \%$, and was $44.8 \%$ after 4 th harnessing stage (1997-2006). With regard to the influence on runoff reduction in the watershed, the contribution rate of human activities was $62.5 \%$ compared with the natural factors after 1st harnessing stage (1970-1979), 28.4\% after 2 nd harnessing stage (1980-1989), in 3rd harnessing stage (1990-1996) it reached 69.6\%, and was 37.0\% after 4th harnessing stage (1997-2006). The results revealed that human activities exerted the largest effects on the sediment reduction and explained $66.6 \%$ of the variation in the specific sediment yield. This study suggests that a combination of human activities and rainfall variation effectively reduces runoff and sediment delivery of the Loess Plateau. Generally The runoff reduction and contribution of rainfall variation to runoff reduction in this area were as large as human activities. After many years' harnessing the great benefit have been obtained in water and soil loss control in this watershed.
\end{abstract}

\section{Introduction}

Rainfall is the primary source of runoff and sediment yield in the middle Yellow River, and in recent several decades for soil erosion control and utilization of water resources, human activity intensity enhanced, the human activities may be another main cause for the variation in runoff and sediment besides the nature factors. In the past few years, with the progress of soil erosion control practices, the amount of sediment and runoff entering the Yellow River has been reduced continuously in areas with high and coarse sediment yield of the Loess Plateau. Some researchers attribute decreased soil erosion mainly to the WSCW, while others believed that it was caused by the rainfall variation. The reduction of runoff and sediment of the watershed cannot be done by simply the soil erosion control practices because the rainfall variation may also have played an important role in the sediment and runoff change. Liu [1] quantitatively analyzed the spatial-temporal evolution pattern of sediment yield in areas with high and coarse sediment yield of the Loess Plateau over the past 50 years, found that the decrease of the amount of sediment entering the Yellow River was caused by the changes of rainfall type in recent years. Ren [2] studied the runoff and sediment yield of Lianshui watershed in different stages by virtue of mathematical model, found that after the 3 soil and water conservation harnessing stages, the sediment yield has significantly decreased, and the annual runoff hasn't been changed along with the extension of the harnessing period. With the fast growth of WSCW-equipped areas, it becomes necessary to clarify the contribution of hydrological impacts soil erosion control to sediment and runoff reduction. The effect of rainfall variation and human activities (particularly WSCW) on runoff generation and soil erosion in the middle Yellow 
River has been an academic focus in recent years [3][4]. Thus, to better predict the impact that rainfall change or a future land-management scenario might have on land-use sustainability, an assessment of the effectiveness of WSCW used to control erosion processes is warranted. However, how to reasonably quantify the impacts of relevant factors on variations in runoff generation and to distinguish the contributions of climate change and human activities still remain as an unsolved theoretical and practical issue. Soil erosion and the resulting runoff and sediment export are caused by stochastic rainfall events and the combined effects of soil, topography, and human activities [5]. Nevertheless, it is necessary to quantify the effects of rainfall variation and human activities on runoff and sediment yield for effective watershed management.

Therefore, in this study the Sanchuanhehe River of Yellow River watershed was chosen as the case study area. The quantitative analysis model and monitoring data were used to explore the the influence of human activities and rainfall variation on sediment and runoff yield. The objectives of this study are the following: (i) to determine how the specific sediment and runoff yield is related to rainfall variation and human activities at the watershed scale; (ii) quantitatively calculate the contribution of long-term soil and water conservation harnessing measures to the runoff and sediment yield of this watershed in different stages and retain it for future reference

\section{Study area}

Sanchuanhe River watershed $\left(36^{\circ} 55^{\prime}-38^{\circ} 10^{\prime} \mathrm{N}\right.$, $\left.110^{\circ} 33^{\prime}-111^{\circ} 36^{\prime} \mathrm{E}\right)$ is located in the areas with high and coarse sediment yield (AHCS) of the Loess Plateau and covers $4161 \mathrm{~km}^{2}$, in the reach from Hekouzhen to Longmen in the middle reaches of Yellow River (Fig.1). This watershed is representative of the AHCS in terms of its natural resources, land-use patterns, and population. Gauge records of the watershed's discharge and sediment yield have been collected since 1957. The area is influenced by dry and continental climates with an average annual precipitation of $506.3 \mathrm{~mm} .73 \%$ of this precipitation occurs in the period of May to September. In this area, the mean annual temperature is $7.3 \sim 10.5^{\circ} \mathrm{C}$, with a minimum mean temperature of $-9.5^{\circ} \mathrm{C}$ in January and a maximum of $24.3^{\circ} \mathrm{C}$ in July. In the summer, intense storms erode much soil; average annual sediment delivery in this area measured $10510 \mathrm{t} / \mathrm{km}^{-2} \mathrm{y}^{-1}$.

The topography of the watershed is characterized by mountain ranges, deep valleys, and loess hilly and gully region; and the elevation ranges from 650 to $1900 \mathrm{~m}$. According to the Chinese soil classification system, the major soil types include brown loamy soil, loessial soil, grey cinnamonic soil, and meadow soil (National Soil Survey Office, 1998). The principal land cover type in this watershed is forest occupying $39.8 \%$ of the watershed area.

In the early 80 s of last century, the soil erosion in local places was very serious, which resulted in riverbed sediment deposition and soil fertility decline and made the ecological environment very fragile. Since 1983 when Sanchuanhe River watershed was listed as one of the 8 key soil and water conservation harnessing regions, the state and local government have done a lot of hard work and effectively carried out many soil and water conservation measures such as soil and water conservation forest, closed forest, aerial tree planting, planting commercial fruit forest and grass, soil-retaining dam construction, etc. Those significant results have been achieved and the ecological environment has been gradually improved. During the period of 1970-2006, large-scale soil and water conservation harnessing was carried out in four stages in Sanchuanhe River watershed. namely, 1st stage: 1970-1979, 2nd stage:1980-1989, 3rd stage:1990-1996, 4th stage:1997-2006. By the end of 2006, the measures of soil and water conservation management area occupies $1735 \mathrm{~km}^{2}$.

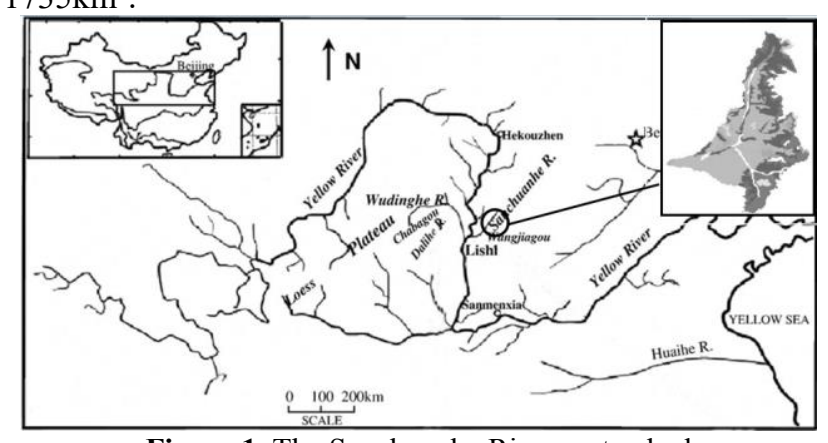

Figure 1. The Sanchuanhe River watershed

\section{Results and discussions}

\subsection{The relationship between precipitation, runoff and sediment}

The relationships between the runoff and the influence factors are constructed through stepwise regression for watersheds using the time series of data over the period of 1957-2006. Figure 2 to figure 4 is the diagram of relationship between precipitation, runoff and sediment in Sanchuanhe River watershed. From the diagram of years' precipitation to runoff (fig.2), precipitation to sediment discharge (fig.3) we can see that, the rainfall change is not consistent with the variation of runoff and sediment in the period of 1997-2006. The precipitation in recent years not has much difference with the precipitation before 1996, but the runoff and sediment discharge was greatly reduced. The relationship between runoff and sediment (Fig.4) is close. The appearance of this phenomenon indicates that the recent reduction in sediment and runoff not only due to the decrease of rainfall intensity, but also has a close relationship with the WSCW, humans consumption etc. 


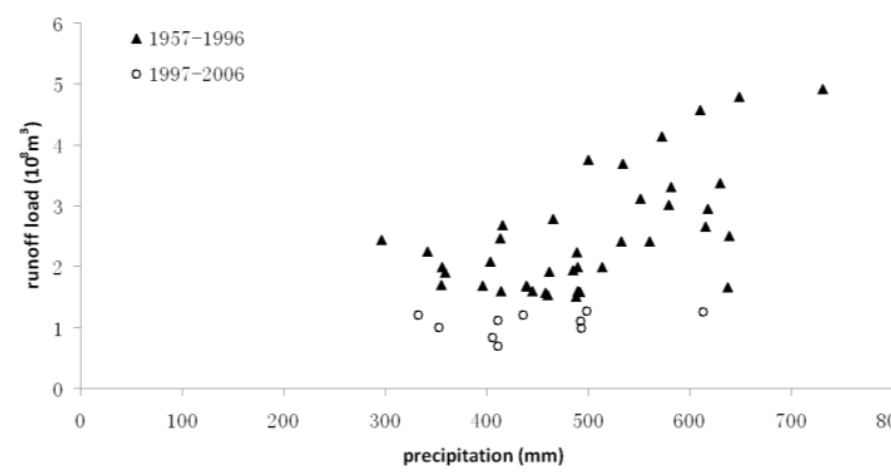

Figure 2. The relationship between the annual precipitation to runoff load

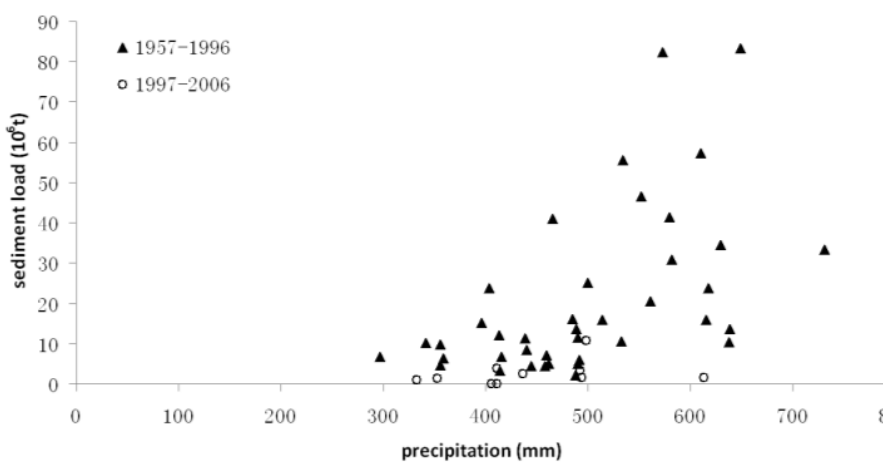

Figure 3. The relationship between the annual precipitation to sediment load

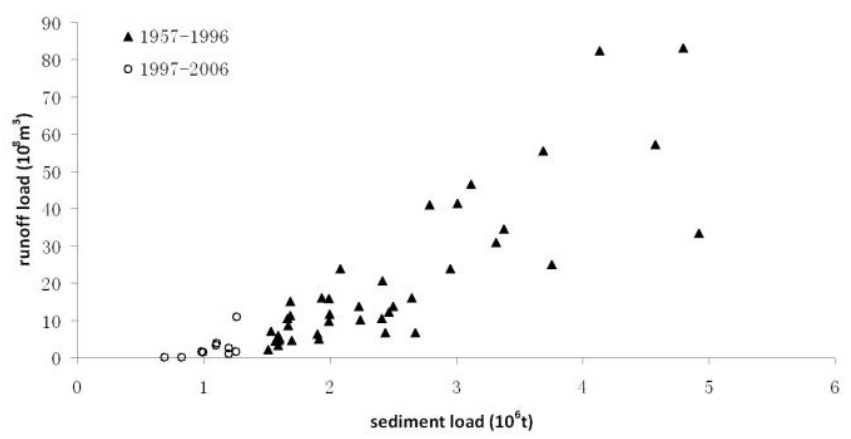

Figure 4. The relationship between the annual runoff load to sediment load

\subsection{Effects of human and rainfall factors in the sediment reduction}

Based on calculating model of Ran built above and the data of climate and water and soil conservation measures, computation is done on the runoff reduction due to soil erosion control practices and climate change. Table. 1 shows estimates of sediment reduction owing to human activities and rainfall factor for the Sanchuanhe River watershed. The actual monitoring data of the monitoring station in this watershed shows that great success has been obtained from the harnessing on soil erosion and the sediment yield has significantly declined. Based on the above results, we can divide the research into five stages now, namely, before the harnessing stage: 1959- 1969, harnessing of the 1st stage: 1970-1979, harnessing of the 2nd stage: 1980 - 1989, harnessing of the 3rd stage: 19901996, harnessing of the 4th stage: 1997- 2006. The proportions of sediment reduction to the annual mean sediment over the period of 1970- 2006 and the percentages of contributions from rainfall variation and 800 from human activities are given in Table 2 . The contribution of different causes to the runoff deviation varied obviously over time. The runoff reduction by rainfall variation is the difference between deviation was over $50 \%$ in the 2 nd stage and 4 th stage. But human activities caused over $98 \%$ of the sediment reduction and rainfall variation contributed a proportion around $2 \%$ in the 3rd stage, the contribution of rainfall variation to the sediment deviation varied obviously over time. The sediment reduction by human activities was 2 times of that by rainfall variation according to their decade means. It can be seen that contribution of rainfall variation to sediment reduction in this area were generally lower than human activities.

Table 1. The proportion of human and rainfall factors in the sediment reduction of the Sanchuanhe River watershed during the stages

\begin{tabular}{|c|c|c|c|c|c|c|c|}
\hline \multirow{2}{*}{$\begin{array}{l}\text { The } \\
\text { stage } \\
\text { (year) }\end{array}$} & \multirow{2}{*}{$\begin{array}{c}\text { The } \\
\text { measur } \\
\text { ed } \\
\text { value }\end{array}$} & \multirow{2}{*}{$\begin{array}{c}\text { The } \\
\text { total } \\
\text { sedimen } \\
\mathrm{t} \\
\text { reductio } \\
\mathrm{n}\end{array}$} & \multicolumn{2}{|c|}{\begin{tabular}{|c|} 
Contribution \\
rate of \\
human \\
activities \\
\end{tabular}} & \multicolumn{2}{|c|}{$\begin{array}{l}\text { Contribution rate } \\
\text { of } \\
\text { rainfall variation }\end{array}$} & \multirow{2}{*}{$\begin{array}{c}\text { The } \\
\text { sedime } \\
\text { nt } \\
\text { reducti } \\
\text { on } \\
\text { benefit } \\
(\%)\end{array}$} \\
\hline & & & $\begin{array}{c}\text { decrem } \\
\text { ent }\end{array}$ & $\begin{array}{c}\text { Propo } \\
\text { rtion( } \\
\%)\end{array}$ & $\begin{array}{c}\text { decreme } \\
\text { nt }\end{array}$ & $\begin{array}{c}\text { Proportio } \\
\mathrm{n}(\%)\end{array}$ & \\
\hline $\begin{array}{c}1957 \sim \\
1969\end{array}$ & 3670 & & & & & & \\
\hline $\begin{array}{c}1970 \sim \\
1979 \\
\end{array}$ & 1822 & 1848 & 1483 & 80.2 & 365 & 19.8 & 44.9 \\
\hline $\begin{array}{c}1980 \sim \\
1989\end{array}$ & 960 & 2710 & 1164 & 43.0 & 1546 & 57.0 & 54.8 \\
\hline $\begin{array}{c}1990 \sim \\
1996\end{array}$ & 1074 & 2596 & 2555 & 98.4 & 41 & 1.6 & 70.4 \\
\hline $\begin{array}{c}1997 \sim \\
2006 \\
\end{array}$ & 257 & 3413 & 1482 & 44.8 & 1931 & 55.2 & 83.6 \\
\hline $\begin{array}{c}1970 \sim \\
2006\end{array}$ & 1028 & 2642 & 1671 & 66.6 & 971 & 33.4 & 63.4 \\
\hline
\end{tabular}

From the table 1, we can get the following conclusion: after the harnessing of the 1st stage, the human activities (namely, the soil and water conservation harnessing) are main factors influencing the sediment yield decreasing of the watershed by around $80.2 \%$ and the rainfall variation by around $19.8 \%$. After the harnessing of the 2 nd stage, the human activities contribution rate to the sediment yield decreased by around $43 \%$ and the rainfall factor by around $57 \%$. After the harnessing of the 3rd stage, the human 
activities contribution rate amounts quickly to $98.4 \%$ meanwhile the rainfall variation accounted for about $1.6 \%$. During the 4th stage from 1997 to 2006, water and soil conservation measures reduced sediment by about 14.82 million $t$ annually for the Sanchuanhe River watershed. On the other hand, the rate of sediment reduction by rainfall variation was about 19.31 million $\mathrm{t}$ per year. Human activities contribution rate to the sediment yield decreased by around $44.8 \%$ and the rainfall factor by around $55.2 \%$. The calculation results also indicate that the human factor can affect the sediment yield significantly, for long-term harnessing, the human factor can change even can decide the change trend of the sediment yield of the watershed. The above analysis of the relationship between runoff coefficient and influencing factors in the spatial dimension has excluded the impacts of water and soil conservation measures on runoff. The decrease of runoff modulus from the early to the later periods under a same climate condition declares that impacts of water and soil conservation measures on runoff has been growing.

\subsection{Effects of human and rainfall factors in the runoff reduction}

Table 2 shows the average runoff reduction due to human activities and rainfall factors in the drainage areas upstream of some hydrological stations. From the table 3, we can get the following conclusion: For different harnessing periods the runoff deviations and contributions of different causes were different. After the harnessing of the 1st stage, the human activities are still main factors influencing the runoff yield decreasing of the watershed and after the harnessing of the 2nd stage, runoff reduction associated with rainfall variation was much higher, rainfall variation caused over $70 \%$ of the runoff reduction and human activities contributed a proportion around $28 \%$. Contribution rate to the sediment yield increased to around $71.6 \%$ and at the end of the harnessing of the 3rd stage, the human activities contribution to total runoff deviations was over $60 \%$. During the 4 th stage, influence of human activities and rainfall variation on the decrease of runoff in each half. It is clear that the decade means of runoff reduction by soil erosion control practices and climate change has a general increasing trend in Sanchuanhe River watershed. The runoff reduction and contribution of rainfall variation to runoff reduction in this area were generally as large as human activities. We find that the human activities can affect the sediment yield significantly, but the reduction benefit on sediment was smaller than runoff, and the contribution rate of human activities and rainfall variation had increased gradually before 2006 and the average runoff reduction benefit is about $44 \%$.

In the period of 1970-2006, human activities reduced runoff by about 33 million $\mathrm{m}^{3}$ annually for the Sanchuanhe River watershed, on the other hand, the rate of runoff reduction by rainfall variation was about 39 million $\mathrm{m}^{3}$ per year (Table 2). The proportions of runoff reduction to the annual mean runoff over the period of 1970-2006 was $49.4 \%$ and the percentages of contributions from climate change was $50.6 \%$. It can be seen that the contribution of rainfall variation to runoff reduction in this area were generally as large as human activities. Even though in the periods of 1971-1990 and 1991-2009 with intensive human activities, the natural factors had still a higher impact on the spatial distribution of runoff coefficient than human activities.

Clearly, although aimed at controlling soil erosion, soil conservation measures not only reduce sediment yield, but also cut down the runoff. Large scale soil conservation practices have been carried out on there in recent decades for reducing the sediment output from the Loess Plateau. Nevertheless, our results also show that the rainfall variation has a sizeable contribution to the runoff decrease in the study area. Similar cases have been reported for many worldwide rivers. In the whole middle Yellow River, climate change contributed over $40 \%$ of the runoff deviations, while water consumption induced also over $40 \%$ runoff reduction in the 1960s, 1970s and 1980s [6]. In Tigray, Northern Ethiopia, the variation in total rainfall amount explained $69 \%$ of the annual runoff volume variability [7].

Table 2. The proportion of human activities and rainfall variation in the runoff reduction of the Sanchuanhe River watershed during the stages

\begin{tabular}{|c|c|c|c|c|c|c|c|}
\hline \multirow{2}{*}{$\begin{array}{l}\text { The } \\
\text { stage } \\
\text { (year) }\end{array}$} & \multirow{2}{*}{$\begin{array}{c}\text { The } \\
\text { measur } \\
\text { ed } \\
\text { value }\end{array}$} & \multirow{2}{*}{$\begin{array}{c}\text { The } \\
\text { total } \\
\text { runoff } \\
\text { reducti } \\
\text { on }\end{array}$} & \multicolumn{2}{|c|}{$\begin{array}{c}\text { Contribution } \\
\text { rate of } \\
\text { human } \\
\text { activities }\end{array}$} & \multicolumn{2}{|c|}{$\begin{array}{c}\text { Contribution } \\
\text { rate of } \\
\text { rainfall variation }\end{array}$} & \multirow{2}{*}{$\begin{array}{l}\text { The } \\
\text { runoff } \\
\text { reductio } \\
n \\
\text { benefit( } \\
\%)\end{array}$} \\
\hline & & & $\begin{array}{c}\text { decrem } \\
\text { ent }\end{array}$ & $\begin{array}{l}\text { Proporti } \\
\text { on }(\%)\end{array}$ & $\begin{array}{c}\text { decrem } \\
\text { ent }\end{array}$ & $\begin{array}{c}\text { Proporti } \\
\text { on( } \%)\end{array}$ & \\
\hline $\begin{array}{c}1957 \sim \\
1969 \\
\end{array}$ & 11521 & & & & & & \\
\hline \begin{tabular}{|c|}
$1970 \sim$ \\
1979 \\
\end{tabular} & 6781 & 4740 & 2962 & 62.5 & 1778 & 37.5 & 30.4 \\
\hline \begin{tabular}{|c|}
$1980 \sim$ \\
1989
\end{tabular} & 4552 & 6969 & 1979 & 28.4 & 4990 & 71.6 & 30.3 \\
\hline $\begin{array}{c}1990 \sim \\
1996\end{array}$ & 4366 & 7155 & 4978 & 69.6 & 2177 & 30.4 & 53.3 \\
\hline $\begin{array}{c}1997 \sim \\
2006 \\
\end{array}$ & 1599 & 9962 & 3477 & 37.0 & 6485 & 63.0 & 62.7 \\
\hline $\begin{array}{c}1970 \sim \\
2006\end{array}$ & 4325 & 7206 & 3349 & 49.4 & 3857 & 50.6 & 44.2 \\
\hline
\end{tabular}

\section{Conclusions}

This paper quantitative analyzed the contribution of WSCW harnessing to the runoff and sediment yield of Sanchuanhe River watershed in different stages by virtue of hydrological simulation model, thus to identify the influence on WSCW harnessing on runoff and sediment yield variation. The test for sediment and runoff prediction shows that the calculating model of Ran can be used to 
predict the annual runoff and sediment in Sanchuanhe River watershed. Analysis of Sanchuanhe River watershed indicates that runoff and sediment showed a clearly decreasing trend over the past 50 years. In the general decrease trend existed two abrupt changes around the years 1971 and 1981. The implementation of soil and water conservation measures in large scale has played great role to reduce the sediment and runoff yield of the watershed, and rainfall factors were of secondary importance. It can be seen that contribution of climate change to sediment reduction in this area were generally lower than human activities. The runoff reduction and contribution of rainfall change to runoff reduction in this area were generally as large as human activities. The contribution rate of these measures to the sediment and runoff yield of the watershed in the four stages from 1970 to 2006 gradually increased along with the spread of the implementation, the contribution rate rising from the initial $44.9 \%$ to $83.6 \%$. The sediment trapping effect of soil and water conservation measures is further improved with the extension of the harnessing time, and the runoff yield capacity also changed greatly, the contribution rate rising from the initial $30.4 \%$ to $62.7 \%$. The above-mentioned analysis shows that the large-scale soil erosion harnessing started in last century is rather proper on the principles of taking watershed as unit and harnessing by unit. After many years' harnessing the great benefit have been obtained in the reforestation and effective sediment trapping in this watershed.

\section{Acknowledgments}

This paper is based on work supported by an open project of the key laboratory (201801) and the Natural Science Foundation of China (51409110).

\section{References}

1. Liu, J.H., Wang, G.Q., Li, H.H., Gong, J.G., Han, J.Y., 2013. Water and sediment evolution in areas with highland coarse sediment yield of the Loess Plateau. International Journal of Sediment Research, 28, 448-457.

2. Ren, S. M., Liang, Y., Sun, B., 2011. Quantitative analysis on the influence of long-term soil and water conservation measures harnessing on runoff and sediment yield of watershed. Procedia Environmental Sciences, 10, 1732-1740.

3. Xu, Z.X., Zhao, F.F., Li, J.Y., 2009. Response of streamflow to climate change in the headwater catchment of the Yellow River basin. Quaternary International, 208 (2009), 62-75.

4. Xu, J.X., 2005. Temporal variation of river flow renewability in the middle yellow river and the influencing factors. Hydrological Processes, 19, 1871-1882.
5. Wei, W., Chen, L.D., Zhang, H.D., Chen, J.,2015. Effect of rainfall variation and landscape change on runoff and sediment yield from a loess hilly catchment in China. Environmental Earth Sciences, 73, 1005-1016.

6. Shi, C.X., Zhou, Y.Y., Fan, X.L., Shao, W.W., 2012. A study on the annual runoff change and its relationship with water and soil conservation practices and climate change in the middle Yellow River basin. Catena, 100, 31-41.

7. Girmay, G., Singh, B.R., Nyssen, J., Borrosen, T., 2009. Runoff and sediment-associated nutrient losses under different land uses in Tigray, Northern Ethiopia. Journal of Hydrology 376, 70-80. 